\title{
From Expatriate Labour to Localisation: A Milestone Analysis of Botswana Education Sector 2008 - 2014
}

\author{
Clarence Itai Mhizha* Bonang S. Mojewa \\ Department of Business Management, BA ISAGO University, Private Bag 149, Gaborone
}

\begin{abstract}
Government of Botswana embraced a policy of citizen economic empowerment in its development planning process. Prior to, and after formalisation of such policies in 2012, a number of programmes and policies aimed at supporting citizen economic empowerment have been implemented (Government Paper NO. 1 OF 2012). The Localisation Policy gives preference to employment of Batswana over non-citizens with similar educational and training qualifications. This paper sought to do an impact analysis of the localisation policy with specific reference to the education sector. The policy on localisation like other empowerment policies was not limited to only one sector of the economy but to all. The period 2008 - 2016 was covered. This paper will however limit its analysis of the localisation milestones achieved in the education sector for the period 2008-2014. Analysis relied much on a self-study approach by reporting and analysing statistics published by the Government of Botswana themselves. The analysis put into consideration that in their policy document Botswana Government states clearly that they will not only train for the local market when they state that "to this end, Botswana will adopt global standards in providing for the necessary human resources needs of domestic enterprises and ensure that Batswana skills are marketable in the global labour market (Government Paper NO. 1 OF 2012:1-2)." The paper adopted a secondary research approach in which related literature (Government of Botswana policy paper on localisation Paper No. 1 OF 2012, Botswana labour statistics report 2011; 2014; Statistics Botswana Annual Report 2015/2016, Bank of Botswana annual report 2015; Statistics Botswana Selected Statistical indicators 1966-2016; and other general literature) were perused and analysed.

Key findings revealed that expatriate numbers in the education sector were on a year to year increase between 2008 and 2011. In 2008, there were 427 permit holders in the education sector compared to 925 in 2011. The trend however improved from 2012 to 2014. Significant decrease of expatriate teachers was experienced. The decreases were significate from 925 in 2011 to 526 in 2012 and 474 and 476 in 2013 and 2014 respectively. This aforementioned analysis depicts a struggle in implementation in the early years of the project which could be due to different reasons which this research does not intend to address.
\end{abstract}

Keywords: Expatriate Labour, Botswana Education

DOI: $10.7176 / \mathrm{JESD} / 11-12-14$

Publication date:June 30th 2020

\subsection{Introduction}

Government of Botswana Paper NO. 1 of 2012:1 states that "Government of Botswana has, over the years, embraced citizen economic empowerment in its development planning process though without a formal policy until 2012. Prior to, and after formalisation of such policies in 2012, a number of programmes and policies aimed at supporting citizen economic empowerment have been implemented." Among the several initiatives is the localisation policy. According to Government Paper NO. 1 OF 2012:1 "the Localisation Policy gives preference to employment of Batswana over non-citizens given similar educational and training qualifications" The period 2008 - 2014 gives us a mathematical seven years of formalised policy implementation on localisation (Government Paper NO. 1 OF 2012:1). The policy on localisation like other empowerment policies was not limited to only one sector of the economy but to all. This paper will however limit its analysis of the localisation milestones achieved in the education sector for the period 2008-2014. Analysis of milestones achieved in respect of localisation of jobs in the education sector in Botswana is imperative for purposes of providing implementers and general readership an appraisal of the progress made. Analysis will rely much on a self-study approach by reporting and analysing statistics published by the Government of Botswana itself. It will also be put into consideration that in their policy document Botswana Government states clearly that they will not only train for the local market when they state that "to this end, Botswana will adopt global standards in providing for the necessary human resources needs of domestic enterprises and ensure that Batswana skills are marketable in the global labour market (Government Paper NO. 1 OF 2012:1-2).”

\subsection{Study Background}

Although there has been international movement of educators for at least as long ago as when the ancient Greeks first tutored the Romans, the advent of 'globalisation' in the 1990s has seen such migration return to prominence (Appleton, Sives and Morgan 2006). As neighbouring countries, South Africa and Botswana invite comparison. Not only do they share some geographic similarities, they are also at similar levels of socio-economic development. 
South Africa is the most economically advanced sub-Saharan economy, but Botswana's 'growth miracle' has meant that it is now approaching its neighbour in terms of income (Appleton, Sives and Morgan 2006). In Botswana recruitment of foreign teachers has occurred primarily as a result of the rapid expansion of the education system since independence in 1966. Botswana should benchmark with countries like China and South Korea whereby importation of foreign teachers is common in foreign languages. It is imperative for Botswana to find a way in order to categorize which skills are lacking in education sector.

\subsection{Statement of the problem}

National Governments, especially in developing economies continue to export labour as a measure to attract foreign currency from workers' remittances. It is apparently interesting to analyse how Botswana has managed to balance the need to export labour and the drive for localisation with specific reference to the education sector in the period 2008 to 2014. While importation of expatriates can bear some benefits Botswana must also take advantages of exporting its labour in critical areas. Is there anything that can be done?

\subsection{Literature review}

1.4.1 Botswana brief History

Botswana gained its independence from Britain in 1966 and since then the economy has continued to grow from an impoverished country sending its citizens out of the country for employment to one receiving skilled professionals from across the continent (Lefko Everett, 2004). The period beginning 1970s marked economic growth in Botswana that required labour and expertise from outside its own boarders. Molutsi (2009:136) posits "having inherited a largely illiterate population at independence in 1966, post-independent Botswana has had to invest heavily in education and training in its first three decades." The Botswana Government had to fill this gap through an open migration policy which exists to this day. Foreign workers have lately been aggressively pursued to fill skills gaps in sectors that include but not limited to technology, management, education, engineering, law, and healthcare (Lefko Everett, 2004).

Commenting on tertiary education in Botswana Molotsi (2009:136) states "like many other countries around the world, Botswana began a major programme of reform of its tertiary (post-secondary) education system at the beginning of the 1990s. The reforms focus on increasing access to, and equity in, tertiary education; improving the quality of provision; ensuring the relevance of programmes to the needs of the learners and society; and promoting a focus on research and development." All this has to happen with solid manpower base which Botswana had but not sufficient to meet demand. The labour supply landscape has since improved especially post 1996 when the then tertiary education council licenced and regulated private education providers to complement the public institutions in the field of training and development. It however, appears that employment of expatriates continue to be an option for most private tertiary institution and it is on the premise of this observation that this paper sought to evaluate the milestones towards localisation over the years 2008 - 2016. 


\subsubsection{Botswana Historic Demographics Statistics}

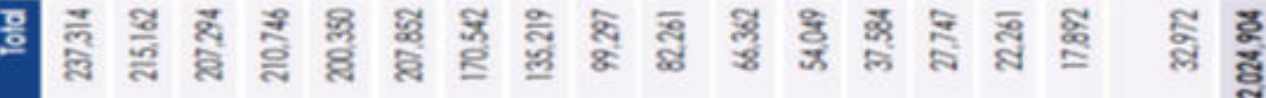

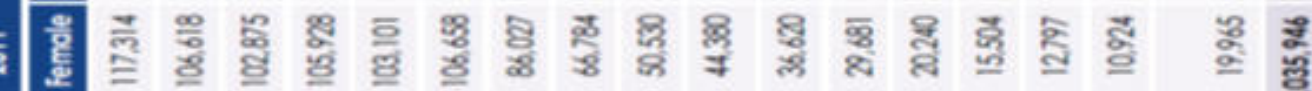

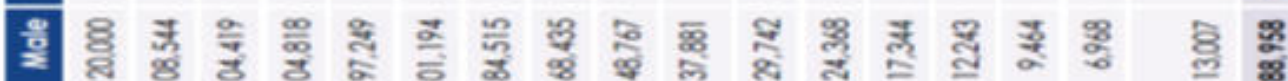

푱 궁 \& 8 잉

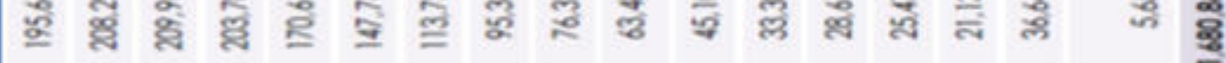

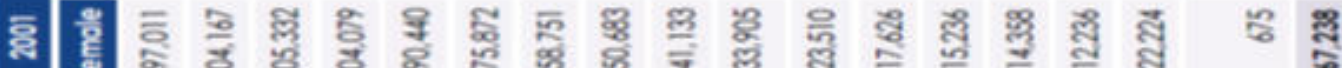

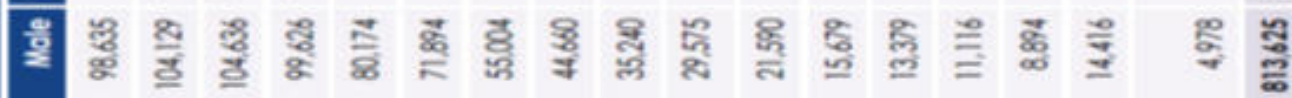

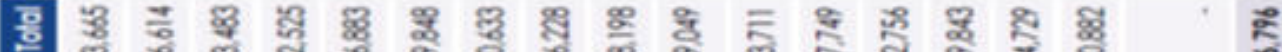

इ

$\bar{\Phi}$

事

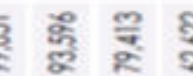

悉 产

₹

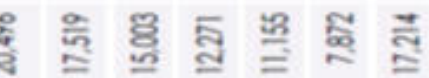

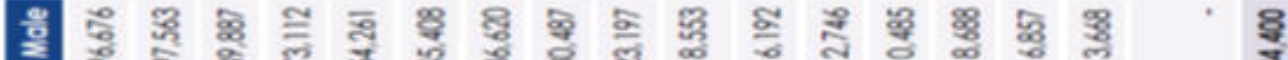

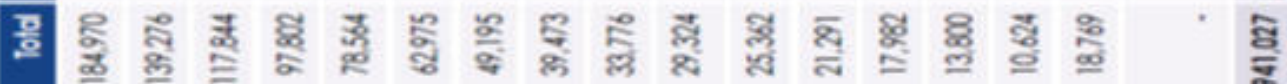

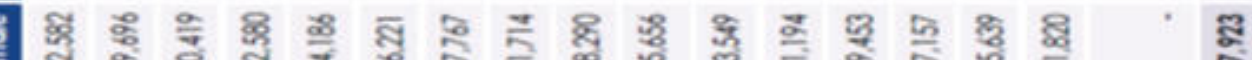

产 흏

$\overline{\bar{\varepsilon}}$

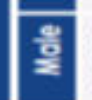

多

ॠ

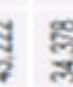

范 卷

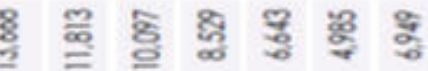

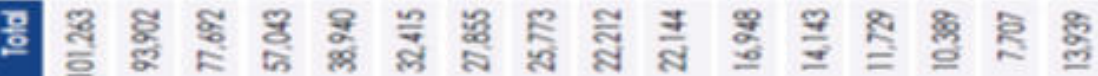

क्ष

Figure 1.1: Botswana Population figures 1971- 2011

Source: Statistic Botswana 2016:53

\begin{tabular}{|r|r|r|r|r|}
\hline 2012 & 2013 & 2014 & 2015 & 2016 \\
\hline $2,070,984$ & $2,114,890$ & $2,156,366$ & $2,195,134$ & $2,230,905$ \\
\hline
\end{tabular}

Figure 1.2: Botswana projected Population figures 2012- 2016

Source: Statistic Botswana 2016:54

From figures 1 and 2 above, it can be deciphered that the Botswana population has been growing on an upward trend since 1971. As of 2016, the population was projected at 2230905 (Statistic Botswana 2016:54). This population includes all citizens including those below and over the employment age. To inform the analysis on localisation milestones, it is imperative to also give a picture of the demographics by age and gender as part of the literature. To inform the research, we will compare the 2001 demographics to the 2011 demographics. It is 
assumed this comparison will put detail in the population statistics presented earlier.

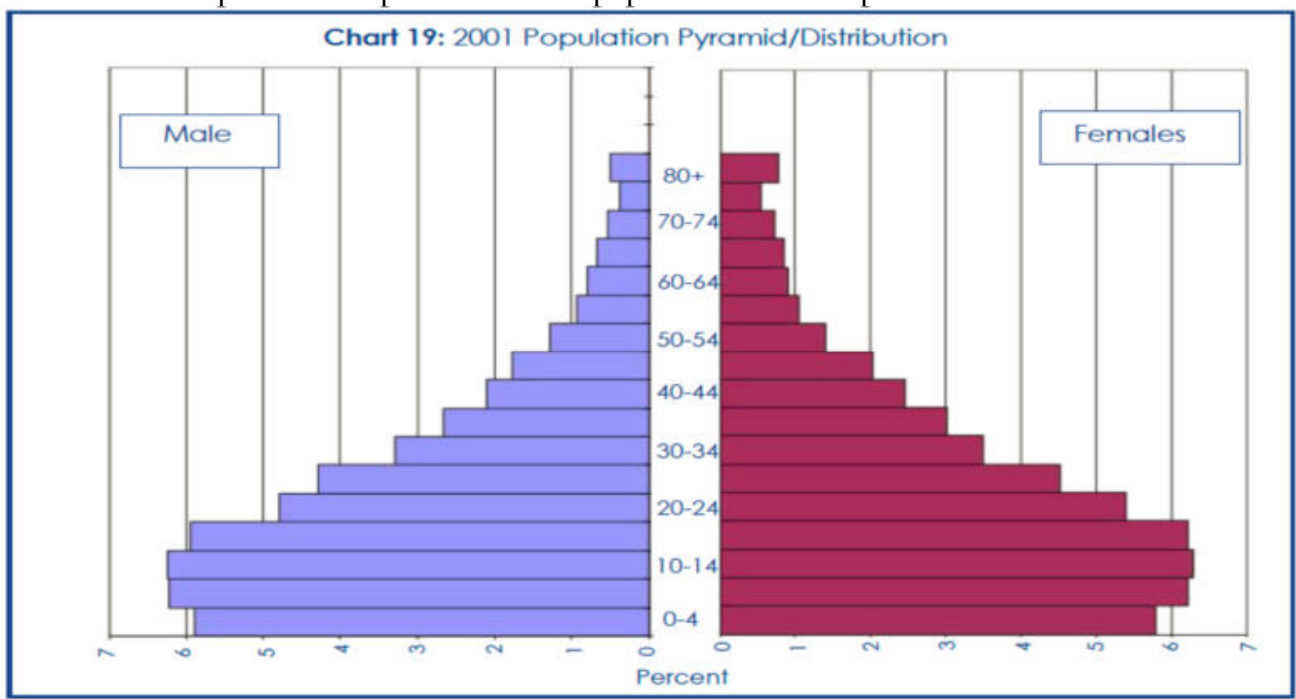

Figure 1.3 a: 2001 Botswana Population distributions

Source: Statistic Botswana 2016:50

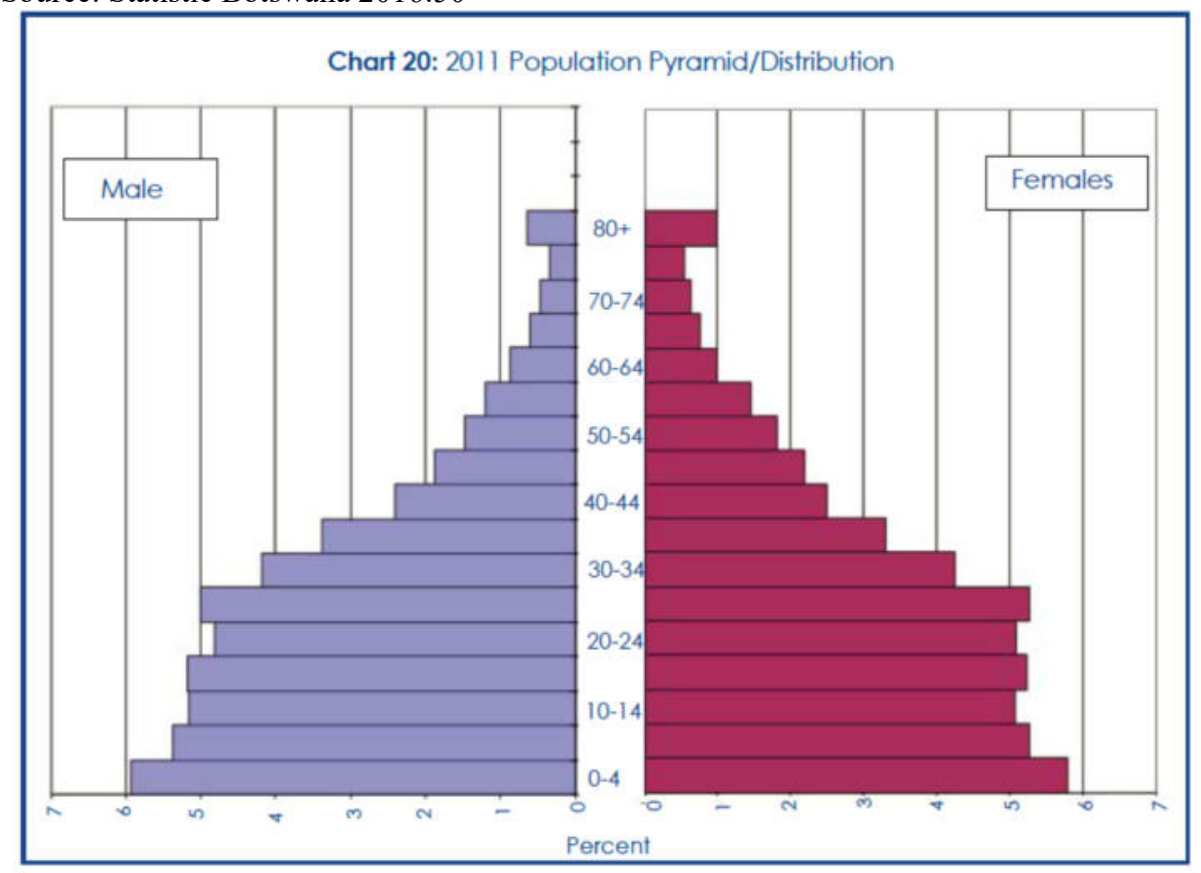

Figure 1. 3 b: 2011 Botswana Population distributions

Source: Statistic Botswana 2016:50

The ten years 2001-2011 indicates that there were more females in the population of Botswana than males. Specific statistics are provided in the table below.

\begin{tabular}{|r|r|r|r|r|r|}
\hline \multicolumn{3}{|c|}{2001} & \multicolumn{3}{c|}{2011} \\
\hline Male & Female & Total & Male & Female & Total \\
\hline 813,625 & 867,238 & $1,680,863$ & 988,958 & $1,035,946$ & $2,024,904$ \\
\hline
\end{tabular}

Figure 1.3.c: Botswana Population distributions 2001 and 2011

Source: Statistic Botswana 2016:52

1.4.3 General world International labour perception

International labour migration ranks high on the international, regional and national policy agendas and has emerged as a major global issue that affects most nations in the world (International Labour Organization, 2010). 
Speaking in support of the attention that the area of international labour has lately been receiving, the International Labour Organization (ILO) has made the Migration for employment part of its global agenda. Further the ILO framed a vision in 2008 premised around Decent Work for all in its Declaration on Social Justice for a Fair Globalization.

National Governments, especially in developing economies continue to export labour as a measure to attract foreign currency from workers' remittances. Besides, the skills acquired during their migration employment will also be useful to their home countries on return. The downside of the migration process is that many migrant workers, especially low-skilled workers, face exploitative working conditions and enjoy only limited human and labour rights.

1.4.4 Migration and employment

"Economic migration plays a role in meeting the needs of the labour market and contributes to reducing skills shortage in the economy (Sepp and Frear, 2011)." Sepp and Frear, (2011) further contend that migrants present a valuable resource that creates value and experience besides relieving labour shortages in specific areas especially those jobs that are increasingly avoided by the native-born (Sepp and Frear, 2011). According to Damette and Fromentin (2013) neither public opinion nor evidence-based research supports the claim of some politicians and the media that immigrants take the jobs of native-born workers. Public opinion polls in six migrant-destination countries after the 2008-2009 recession show that most people believe that immigrants fill job vacancies and many believe that they create jobs and do not take jobs from native workers. "This view is corroborated by evidencebased research showing that immigrants of all skill levels do not significantly affect native employment in the short term and boost employment in the long term (OECD,2016a)."

According to Constant and Zimmermann (2012) immigration's positive effects far outweigh any negative impact. Migrants choose locations with available jobs and fill labour shortages. Whether high or low-skilled, migrants rarely substitute directly for native workers the author adds. Furthermore Constant and Zimmermann (2012) argue that instead migrants often complement native workers or accept jobs that natives don't want or can't do. "They also provide opportunities for native workers to upgrade their occupation and specialize in higher-skill jobs. The presence of immigrants increases demand and can spur new businesses to open, creating more jobs for immigrant and native populations" (Constant and Zimmermann (2012).

1.4.5 The traditional labour market model

According to Organisation for Economic Co-operation and Development (OECD, 2015) the traditional labour market model, with employers on the demand side and employees on the supply side, defines the equilibrium wage and employment at the intersection of demand and supply where employers hire workers they need at this wage, and all employees who want to work at this wage can find a job. In purview of this model, it can be argued that Immigration increases labour supply and in the short term, holding all else constant the increase in labour supply lowers the equilibrium wage and raises the equilibrium level of employment, but it is not clear who gains from the increase in employment (OECD, 2015). The Damette and Fromentin (2013) findings postulates that it is possible that some native workers lose their jobs or drop out of the market and that some immigrants find jobs while others remain unemployed. Furthermore, the economics of migration tell us that a country will always need immigrants because its native labour force is not large enough to meet demand or specialized enough to handle technological changes.

"Studies find no correlation between unemployment and the share of immigrants in a country. Indeed, a study of the effect of increased immigration in Europe in 1991 found that in competitive markets, labour migration increased the efficiency and flexibility of labour markets and slowed wage growth, allowing more people to find jobs (OECD, 2015)." Data from 2001-2007 for 17 Organisation for Economic Co-operation and Development (OECD) countries show similar results (OECD, 2015)."

According to Dustman, Frattini and Preston (2010) there should be a consensus among economists and policymakers about the concept of "labour shortages". It is that the term has no universally agreed upon definition. "There might be an agreement to defining it as a situation where the number of workers in an occupation is less than what is considered the socially desired number, or that demand for labour exceeds supply at the prevailing wages and employment conditions" (Dustmann, Frattini and Preston, 2010). That is if we take into account that all types of jobs require some skill then any kind of inability to fill that job could be described as a skill shortage. This then raises the question of how and where the labour market demand can be satisfied.

The arguments in favour of attracting immigrant workers to solve labour shortages rest partly on the assumption that the resident labour supply is insufficient, or of inferior quality, to meet labour demand. "The need for immigrant labour depends in large part on a country's initial situation. Countries with low unemployment rates and high activity rates might soon exhaust opportunities to retrain unemployed workers and inactive people than countries with a more abundant stock of people not in work" (OECD, 2011).

According to Hunt, (2012), OECD (2016a), OECD (2013), OECD (2007a) a host of other factors also play a role: the willingness to live and work in another region; care- giving tasks within the family; the duration of inactivity; etc. Some of the available reports include explicit attempts to estimate the size of the resident potential 
labour supply. "Initial results indicate that on average for the OECD slightly more than 55 percent of the working age population is in full-time employment. The remainder, 45 percent, is either (partly) unemployed or (partly) inactive and in theory represents the latent labour supply OECD (2007a).

"Some research by the OECD argues that for some countries like the Netherlands and Belgium latent labour supplies are such that general labour shortages are not likely to develop. However, experience shows that it will be very difficult to say anything with any accuracy about the success of any of the attempts to mobilize the unused resident labour force (OECD (2007b))." At the same time, and especially with the recent economic downturn, there are popular concerns that labour immigration is harmful to the position of resident workers. The Irish Employment and Training Authority (FÁS) for example recently claimed that youth unemployment may be rising due to employers' preference for work permit recruits; the FÁS said the number of permits being issued was too high and needed to be reduced when long-term unemployment starts to rise again. Irish labour immigration law has subsequently been toughened (OECD (2007b).

According to Damette and Fromentin (2013), OECD (2007b, immigration has also been a major theme in many of the recent election campaigns in European countries. A number of countries have commissioned macrolevel studies to evaluate current labour shortages, and to estimate the availability of unused labour among native and immigrant inactive and unemployed people, and the remaining long-term need for immigrant workers. "Shortages may be experienced in one sector of the economy or for specific occupations whilst unemployment is high elsewhere. Employer reports and surveys from all over the OECD confirm that shortages occur in specific occupations and are not confined to high qualified jobs OECD (2007a)." However employer judgments have to be treated with caution, as they report on recruitment difficulties but not on labour shortages per se. These specific studies are much more precise but at the same time illustrate the difficulty in predicting the labour demand with any accuracy (OECD 2007a).

Damette and Fromentin (2013) state that Germany, Austria, Norway and the Netherlands for example have undertaken one or a series of studies specifically to answer the question whether labour migration can play a role in alleviating current and future labour shortages. These studies agree that immigration can contribute in a significant way to welfare and economic growth, but show no uniformity about the causes of labour shortages. In fact, the way in which labour shortages are defined differs in each. "This means that labour shortages are not easy to measure, but it also implies that the need for labour migration cannot be expressed in terms of precise numbers of people with specific skills for a well-defined time period. There is no universally applied definition of labour shortages. In part this reflects the fact that they are not easy to measure (Damette and Fromentin, 2013).

"Economic, demographic and political developments, combined with the mounting concern about the future of labour supply have renewed the attention of policy-makers on labour migration issue (OECD (2015d)." Demographic developments in OECD countries imply an ageing workforce and ultimately result in a declining population of working age thus also result in labour shortages. Employers started to experience difficulties in filling vacant posts, concerns about the availability of labour on domestic markets arose and the first calls for immigrant labour echoed. Countries are faced with the urgent need to meet a growing demand for workers with specific skills in certain sectors; some countries have already started to facilitate labour market access for skilled immigrant workers. Some countries have considered recruitment of immigrants on the basis of their human capital, i.e., through selective immigration, to compensate for an ageing workforce Damette and Fromentin (2013)

1.4.6 Employer's Practices in Hiring Expatriates: A general analysis

According to Kyrieri and Roidou (2012), McKinsey Global Institute (2017), using the migrant labour force includes a variety of direct advantages for employers. This is because of the 'national stereotyping' in the recruitment of labour which is affected by the workers' expectations about wages and employment conditions as well as by their 'work ethic' and productivity. That is employers are aware of the economic and other trade-offs that migrants are willing to make by tolerating wages and employment conditions that are poor by the standards of their host country, but higher than those in their countries of origin. At the same time, existing studies often refer to employers' comments concerning migrants' perceived superior 'attitude' and work ethic. The explanations behind immigrants' higher 'work ethic' stem from migrants' frames of reference and their willingness to do the job on the employers' terms (Kyrieri and Roidou, 2012).

Kyrieri and Roidou (2012) argue that the preference towards immigrants also has its origins in the characteristics and restrictions attached to their immigration status. Immigration policies include a range of different types of status such as work-permit holder, student, working holiday-maker, and dependent relative. Each of these types is associated with specific rights and restrictions that cannot be imposed on citizens and may give rise to a specific demand for particular types of migrant workers. "Whenever faced with difficulty in finding or retaining workers in certain jobs, employers may prefer workers whose choice of employment is restricted, as it is usually the case with recent arrivals and migrants on temporary visas (Kyrieri and Roidou, 2012)." 


\subsection{Methodology}

1.5.1 Research Design

This paper adopted a secondary research approach in which related literature (Government of Botswana policy paper on localisation Paper No. 1 OF 2012, Botswana labour statistics report 2011; 2014; Statistics Botswana Annual Report 2015/2016, Bank of Botswana annual report 2015; Statistics Botswana Selected Statistical indicators 1966-2016; and other general literature) were perused and analysed.

1.5.2 Research Objectives:

The objectives of this paper are to:

1. Discuss localisation developments in Botswana education Industry in the context of theory

2. Measure the extent of success of the Botswana localisation policy in the education sector for the period 2008 2014

3. Make recommendations in relation to the trends observed in the research.

\subsection{Findings, conclusions and Recommendations}

The tables below show the estimated number of Paid Employees in Education Sector 2008 - 2011 expressed in the last row as a percentage of the total number of paid employees in all Sectors in Botswana and estimated work permit holders.

Table 1.1 Estimated numbers of Paid Employees in Education Sector 2008 - 2011

\begin{tabular}{|l|l|l|l|l|l|l|l|l|l|l|l|l|}
\hline \multicolumn{3}{|c|}{$\mathbf{2 0 0 8}$} & \multicolumn{4}{c|}{$\mathbf{2 0 0 9}$} & \multicolumn{3}{c|}{$\mathbf{2 0 1 0}$} & \multicolumn{2}{c|}{2011} \\
\hline Mar & June & Sept & Mar & Jun & Sept & Dec & Mar & Jun & Sept & Dec & Mar & Jun \\
\hline 9400 & 9700 & 9700 & 9700 & 9800 & 9900 & 9800 & 9800 & 9900 & 10000 & 9900 & 10000 & 10100 \\
\hline $3 \%$ & $3.1 \%$ & $3.1 \%$ & $2.5 \%$ & $2.5 \%$ & $2.7 \%$ & $2.9 \%$ & $2.7 \%$ & $2.7 \%$ & $2.7 \%$ & $2.6 \%$ & $2.6 \%$ & $2.6 \%$ \\
\hline
\end{tabular}

Source: Labour Statistics Report: Statistics Botswana (2011:12)

Table 1.2 Permit holders in the education sector $2008-2014$

\begin{tabular}{|c|c|c|c|c|c|c|}
\hline $\mathbf{2 0 0 8}$ & $\mathbf{2 0 0 9}$ & $\mathbf{2 0 1 0}$ & $\mathbf{2 0 1 1}$ & $\mathbf{2 0 1 2}$ & $\mathbf{2 0 1 3}$ & $\mathbf{2 0 1 4}$ \\
\hline 424 & 768 & 815 & 925 & 526 & 474 & 476 \\
\hline
\end{tabular}

Source: Labour Statistics Report: Statistics Botswana (2014)

1.6.1 Statistics Botswana (2011:26) states, "formal non-citizen employment estimates are mainly obtained in two ways, first as a result of information from employment surveys conducted yearly during March, June, September and December, and secondly from processing of work-permits."

1.6.2 According to Statistics Botswana (2011:26) total work permit holders in the education sector constituted $2.2 \%$ of total work permit holders in all industries. In 2011, the total permit holders in Botswana stood at $6 \%$. This indicates a $3.8 \%$ increase compared to the previous year. In terms of average earnings Statistics Botswana (2011:34) reports that as at March 2011 the male non-citizen employee was earning P13,097 on average compared to P10,416 by the male citizen (Average margin of P2,681 in favour of the non-citizen male). On the female side, as at March 2011, the female non-citizen on average earned P9, 342 compared to P 6,062 earned by their citizen female counterparts (Average margin of P3, 280 in favour of the non-citizen female).

1.6.3 As at June 2011, the male non-citizen employee was earning P12, 446 on average compared to P9, 470 by the male citizen (Average margin of P2, 976 in favour of the non-citizen male). On the female side, as at June 2011, the female non-citizen on average earned P9, 933 compared to P6, 531 earned by their citizen female counterparts (Average margin of P3, 402 in favour of the non-citizen female).

\subsection{Conclusion}

A bird's view analysis of the trend of figures of expatriates in the education sector suggests a steep increase in expatriate numbers year in year out between 2008 and 2011. This observation appears to obtain explanation from the remuneration trends that were being applied where expatriates appeared to earn higher hence that should have become a pull factor for expatriate teachers mainly from the neighbouring countries especially Zimbabwe which during the period in question was going through a harsh economic experience after the 2008 elections.

The statistics however, provides an encouraging picture to its sponsors from 2012 to 2014. During these three years, there was a significant decrease of expatriate teachers from 925 teachers in 2011 to a $50 \%$ low of 476 in 2014. Thus there was significant achievement of the localisation policy with a consistent downward trend over three years.

Since this study covered period 2008-2014 it is recommended that other scholars can expand this study to see how the trends are as of up to year 2019.

\subsection{Recommendations}

1.8.1The period 2008 to 2011 lessons in terms of employment conditions must never be repeated as they are likely to reverse the gains of 2012 to 2014 . 
1.8.2The policy framework adopted between 2012 and 2014 in respect of the localisation agenda should be considered for continuation as its results speak much of success that failure in terms of localising labour in the education sector.

1.8.3 Botswana should aim at empowering its citizens with skills at postgraduate level in order to reduce number of expatriates. If this is done efficiently the country would only need to bring in high skilled labour of scarce skills. 1.8.4 Botswama should also look into exporting some of its excess labour in order to curb its current estimate $37.5 \%$ youth unemployment.

1.8.5 While it is good for a country to have expatriates, Botswana should also make sure that expatriates do not only offer their expertise but also do skills transfer to locals. This should be a well organised plan.

\section{Possible future research directions}

This paper has only address one sector of employment and gives only a partial picture of the localisation progress. It is recommended therefore that possible future research should explore studying all other sectors of the economy for purposes of evaluating the localisation progress in the sectors.

\section{References}

Appleton, S., Sives, A., Morgan, W. (20060, the impact of international migration on scholling in developing countries-The case of Southern Africa.

https://www.researchgate.net/publication/228673004_The_impact_of_international_teacher_migration_on_scho oling_in_developing_countries-the_case_of_Southern_Africa accessed on 18 May 2020

Constant, A.F. and Zimmermann, K.F. (2012). The dynamics of repeat migration: A Markov chain analysis International Migration Review 46:2 (2012): 361-387.

Damette, O. and Fromentin, V., (2013), Migration and Labour Markets in OECD Countries: A Panel Cointegration Approach. Applied Economics 45, 2295-2304.

Dustman. C, Frattini.T and Preston. I. K. (2010), Immigration Sub-National and Regional Labour Shortages.

Hunt, J. (2012), The Impact of Immigration on the Educational Attainment of Natives. NBER Working Paper No. 18047

Kyrieri, Katerina-Marina and Roidou, Eleni (2012) Satisfying Labour Demands in Mid- and Low-Skilled Occupations through Immigration. EIPA Scope, 2012 (1). pp. 37-42. ISSN 1025-6253.

McKinsey Global Institute (2017), A Future that Works: Automation, Employment, and Productivity, McKinsey \& Company.

Government of Botswana (2012). Government Paper NO. 1 OF 2012. The Citizen Economic Empowerment Policy. Cited from http://bbbee.typepad.com

Molutsi, P. (2009) Tertiary education reforms in Botswana. http://www.cedol.org/wpcontent/uploads/2012/02/136-138-2009.pdf

OECD (2015c), OECD Employment Outlook 2015, OECD Publishing, Paris. http://dx.doi.org/10.1787/empl_outlook-2015-en.

OECD (2015d), Activation policies for more inclusive labour markets", in OECD (2015), OECD Employment Outlook 2015, OECD Publishing, Paris. http://dx.doi.org/10.1787/empl_outlook-2015-7-en

OECD (2014), Non-regular employment, job security and the labour market divide", in OECD (2014), OECD Employment Outlook 2014, OECD Publishing, Paris. http://dx.doi.org/10.1787/empl outlook-2014-7-en

OECD (2013), OECD Skills Outlook 2013: First Results from the Survey of Adult Skills, OECD Publishing, Paris. http://dx.doi.org/10.1787/9789264204256-en

OECD (2012), Policy Priorities for International Trade and Jobs, (ed.), D. Lippoldt, e-publication, available at: www.oecd.org/trade/icite.

OECD (2007a), Globalisation, Jobs and Wages, Policy Brief, June 2007. https://www.oecd.org/els/emp/Globalisation-Jobs-and-Wages-2007.pdf

OECD (2007b), Offshoring and Employment: Trends and Impacts, OECD Publishing, Paris. http://dx.doi.org/10.1787/9789264030947-en

Statistics Botswana (2011). Labour Statistics Report 2011. Accessed from www.statsbots.org.bw

Statistics Botswana (2014). Labour Statistics Report 2011. Accessed from www.statsbots.org.bw

Statistics Botswana (2015).Labour Statistics Report 2011. Accessed from www.statsbots.org.bw 